\title{
Determining the optimal ratio of canola meal and high protein dried distillers grain protein in diets of high producing Holstein dairy cows
}

\author{
N. Swanepoel ${ }^{a, b, *}$, P.H. Robinson ${ }^{b}$, L.J. Erasmus ${ }^{a}$

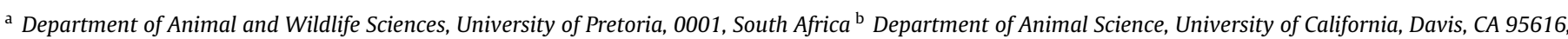 \\ USA
}

Corresponding author at: University of California, 2251 Meyer Hall, Davis, CA 95616, USA. Tel.: +1 530752 7076; mobile: +27 798918920.

E-mail address: nanswanepoel@gmail.com (N. Swanepoel).

Keywords:

Milk production

Spot urine purine

Plasma amino acids

\section{A B S T R A C T}

Use of canola meal (CM) and dried corn distillers grains with solubles (DDGS) as major supplemental protein sources are common practice in North American dairy rations and usage of both is projected to increase in the future. Since limited data is available on performance of cows fed diets with different ratios of CM and DDGS, our objective was to determine the optimal ratio of CM to DDGS protein in a contemporary lactation dairy ration by feeding combinations of CM and high protein DDG (HPDDG) to early lactation multiparity dairy cows. The experiment was a $4 \times 4$ Latin square with $28 \mathrm{~d}$ periods using four pens of $\sim 320 \mathrm{high}$ producing cows/pen. Treatments were created by varying the amounts of CM and HPDDG added on a DM basis to be: (1) $0 \mathrm{~g} / \mathrm{kg} \mathrm{CM}$ and $200 \mathrm{~g} / \mathrm{kg}$ HPDDG, (2) $65 \mathrm{~g} / \mathrm{kg} \mathrm{CM}$ and $135 \mathrm{~g} / \mathrm{kg}$ HPDDG, (3) $135 \mathrm{~g} / \mathrm{kg} \mathrm{CM}$ and $65 \mathrm{~g} / \mathrm{kg}$ HPDDG, (4) $200 \mathrm{~g} / \mathrm{kg}$ CM and $0 \mathrm{~g} / \mathrm{kg}$ HPDDG. Dry matter intake was not affected by the CM/HPDDG ratio in the ration. Milk and lactose yield, true protein (TP) content and yield, milk fat yield as well as milk energy output increased at a decreasing rate with a higher CM/HPDDG ratio. Maximum values for milk and TP yield were at $\sim 135 \mathrm{~g} / \mathrm{kg} \mathrm{CM}$, while lactose, TP content and milk energy were maximized at $\sim 120 \mathrm{~g} / \mathrm{kg}$ CM inclusion. Milk fat content and milk energy density decreased linearly with higher CM inclusion. Body condition score change responded quadratically with the highest gain at $\sim 120 \mathrm{~g} / \mathrm{kg}$ CM inclusion. The purine derivative to creatinine index increased linearly with higher CM inclusion levels, suggesting that microbial protein production (MCP) was limited in the $0 \mathrm{~g} / \mathrm{kg} \mathrm{CM}$ ration and was progressively stimulated by higher feeding levels of CM. Plasma AA levels suggest that the reduction in lysine in dietary protein, together with the decrease in $\mathrm{MCP}$ production, resulted in a substantial reduction in lysine available for milk production, thereby limiting performance in the higher HPDDG ration. The only AA which decreased in plasma with higher CM feeding levels were phenylalanine, leucine and methionine. That the level of leucine in the plasma was still decreasing linearly, while methionine and phenylalanine responded quadratically at the $200 \mathrm{~g} / \mathrm{kg} \mathrm{CM}$ treatment, was interpreted to suggest that the leucine supply remained higher than its requirement at the highest $\mathrm{CM}$

Abbreviations: AA, amino acids; ADF, acid detergent fiber; ADICP, AD insoluble CP; AL, allantoin; aNDF, amylase-treated NDF; aNDFom, aNDF free of residual ash; AP, absorbable protein; BCS, body condition score; BUN, blood urea N; BW, body weight; CM, canola meal; CP, crude protein; CR, creatinine; DC305, DairyComp 305 management system; DDGS, dried distillers grains with solubles; DHIA, Dairy Herd Improvement Association; DIM, days in milk; DM, dry matter; EAA, essential AA; HPDDG, high protein DDG; MCP, microbial CP; NDF, neutral detergent fiber; NE , net energy for lactation; OM, organic matter; PD, purine derivatives; PDC index, PD to creatinine index; RDP, rumen degradable CP; RUP, rumen undegradable CP; SCC, somatic cell counts; TMR, total mixed ration; TP, true protein. 
inclusion level, but that phenylalanine and/or methionine was limiting production in the highest CM ration. Overall, results suggest that the optimum ratio of CM to HPDDG in these diets was with $120-135 \mathrm{~g} / \mathrm{kg}$ of diet DM from CM.

\section{Introduction}

Protein nutrition is critical for high production efficiency of lactating dairy cows because it impacts their performance and the environment. Sufficient dietary protein is required to optimize production while an excess has negative effects on the environment, primarily when excreted as urea in urine. The major protein sources used in western areas of North America include high quality alfalfa hay, whole cottonseed or cottonseed meal, dried distillers grains with solubles (DDGS) and canola meal (CM). Due to the variable quality and high price of alfalfa hay, and the presence of secondary compounds (i.e., tannins and gossypol) in cottonseed, their inclusion levels in dairy rations are limited. Therefore, use of CM and DDGS as major supplemental protein sources is currently very high in many US dairy rations.

The Canola Council of Canada developed an initiative (Growing Great 2015) which aims to double 2011 production of CM by 2015 through increased crushing capacity in Canada (Canola Council of Canada Annual Reports, 2010, 2011). The USA is the main market for CM exports from Canada, receiving over 50\% of their total CM exports with over $90 \%$ of this imported CM being utilized by the California dairy industry (USDA, 2011; Nernberg, 2012). Due to steadily increasing crude oil prices, the corn ethanol production industry in the Midwestern USA has been expanding rapidly since 2000, and increased production of corn distiller's grains, the major by-product of the corn-starch ethanol industry, is projected to continue in coming years, at least as long as government subsidies persist (Wisner, 2010). As supplies of CM and DDGS increase, so will pressure to use these products as major protein supplements in dairy cattle rations. However, with as much as $400 \mathrm{~g} / \mathrm{kg}$ of the crude protein (CP) in contemporary California total mixed ration (TMR) already coming from corn products, which is known to be limiting for milk protein synthesis in some amino acids (AA), particularly lysine, inclusion of even more corn DDGS protein could have a detrimental effect on production due to AA imbalances at the intestinal absorptive site, as well as by adding excess corn oil to already corn oil rich rations.

Studies comparing CM to DDGS have reported that higher proportions of CM, included at up to 66 and $120 \mathrm{~g} / \mathrm{kg}$ DM respectively, tended to have higher absolute values for milk and protein yields (Mulrooney et al., 2009). However, negative effects of high levels of unsaturated fatty acids in corn oil on milk production, often reducing milk fat concentration and yield (Hollmann et al., 2011; Liu and Rosentrater, 2011), necessitates use of a low oil alternative to conventional DDGS when experimentally comparing dietary protein sources involving corn based DDGS. High protein DDG products (HPDDG) provide the opportunity to do this as they have a very similar proximate nutrient profile to CM (Table 1). Christen et al. (2010)

Table 1

Chemical analysis (+ standard errors ${ }^{\mathrm{a}}$ ) of ingredients used in the total mixed rations $(\mathrm{g} / \mathrm{kg}$ dry matter) fed to cows.

\begin{tabular}{|c|c|c|c|c|c|c|}
\hline & Dry matter & Organic matter & Crude protein & $\mathrm{aNDF}^{\mathrm{b}}$ & aNDFom $^{c}$ & Fat \\
\hline \multirow[t]{2}{*}{ Alfalfa, hay } & 912 & 889 & 195 & 391 & 380 & 20.6 \\
\hline & $(1.1)$ & (3.4) & $(2.8)$ & $(10.1)$ & $(10.7)$ & $(0.98)$ \\
\hline \multirow[t]{2}{*}{ Almond, hulls } & 981 & 928 & 48.9 & 332 & 319 & 24.3 \\
\hline & $(0.8)$ & $(2.4)$ & $(2.74)$ & $(21.4)$ & $(18.5)$ & $(0.61)$ \\
\hline \multirow[t]{2}{*}{ Oat, hay } & 918 & 890 & 109 & 560 & 542 & 24.3 \\
\hline & $(0.6)$ & (3.6) & (6.1) & $(3.2)$ & $(2.4)$ & $(0.75)$ \\
\hline \multirow[t]{2}{*}{ Corn, steam flaked grain } & 857 & 986 & 84.4 & 85.0 & 84.5 & 34.6 \\
\hline & $(5.3)$ & $(0.3)$ & $(1.11)$ & $(2.86)$ & $(3.12)$ & $(1.17)$ \\
\hline \multirow[t]{2}{*}{ Cottonseed, cracked Pima } & 915 & 953 & 218 & 403 & 385 & 223 \\
\hline & $(3.4)$ & $(0.8)$ & $(9.8)$ & $(8.9)$ & $(8.1)$ & $(3.2)$ \\
\hline \multirow[t]{2}{*}{ Canola meal, pellets (380 g/kg CP, solvent) } & 893 & 924 & 410 & 271 & 237 & 26.4 \\
\hline & $(5.1)$ & $(1.0)$ & $(2.3)$ & $(5.3)$ & $(7.6)$ & $(1.54)$ \\
\hline \multirow[t]{2}{*}{ Distillers grains, high CP (corn with solubles) } & 915 & 978 & 395 & 338 & 331 & 54.5 \\
\hline & $(1.9)$ & $(7.1)$ & $(6.1)$ & $(30.0)$ & $(29.3)$ & $(2.18)$ \\
\hline \multirow[t]{2}{*}{ Wheat, silage } & 321 & 881 & 82.2 & 537 & 495 & 29.4 \\
\hline & $(6.4)$ & $(1.5)$ & $(6.34)$ & $(8.4)$ & $(6.5)$ & $(0.87)$ \\
\hline \multirow[t]{2}{*}{ Corn, silage } & 331 & 926 & 80.0 & 459 & 447 & 24.8 \\
\hline & $(5.4)$ & $(4.4)$ & $(1.87)$ & $(5.8)$ & $(4.5)$ & $(1.42)$ \\
\hline \multirow[t]{2}{*}{ Citrus, pulp } & 158 & 954 & 72.1 & 189 & 185 & 15.7 \\
\hline & $(4.3)$ & $(3.5)$ & $(3.56)$ & $(10.8)$ & $(9.3)$ & $(0.90)$ \\
\hline \multirow[t]{2}{*}{ Potatoes, tubers (whole) } & 197 & 955 & 79.8 & 57.0 & 55.0 & $<2.5$ \\
\hline & (3.7) & $(2.1)$ & $(4.22)$ & $(2.00)$ & $(1.30)$ & $(-)$ \\
\hline \multirow[t]{2}{*}{ Pomegranate, pulp waste } & 251 & 955 & 99.2 & 301 & 293 & 59.5 \\
\hline & $(19.0)$ & $(2.3)$ & $(17.97)$ & $(46.5)$ & $(46.3)$ & (11.13) \\
\hline
\end{tabular}

a Means and (SE) with a 95\% confidence level. $n=4$, except citrus pulp =3, potatoes $=2$, pomegranate $=2$.

b Neutral detergent fiber assayed with heat stable amylase, expressed inclusive of residual ash.

c Neutral detergent fiber assayed with heat stable amylase, expressed exclusive of residual ash. 
suggested that HPDDG outperformed CM at $120 \mathrm{~g} / \mathrm{kg}$ diet DM, and there were indications that cows fed the HPDDG ration had an improved plasma AA balance versus $\mathrm{CM}$, with a more desirable AA profile for milk protein production. However, adding HPDDG to rations which are already high in corn proteins may lead to lysine becoming limiting to milk production. Also, CM and HPDDG have very different CP degradability profiles with CM being primarily a rumen degradable CP (RDP) source while HPDDG is a high rumen undegradable CP (RUP) source (data summarized by Mulrooney et al., 2009). This means that a higher dietary inclusion level of either could lead to an imbalance in the dietary RDP:RUP ratio, thereby negatively affecting rumen function, and/or creating an imbalance in AA available to support milk production. Few studies have been completed comparing dairy cattle performance between CM and HPDDG directly, and little information is available on inclusion levels higher than $120 \mathrm{~g} / \mathrm{kg}$ for either protein source.

The objective was to determine the optimal ratio of CM to DDGS protein as the sole supplementary dietary protein source in rations which are relatively high in corn proteins, provided as corn grain and corn silage, by feeding combinations of CM and HPDDG to high producing dairy cows, thereby comparing the two protein sources without negative confounding effects from corn oil in conventional DDGS.

\section{Materials and methods}

The experiment was a $4 \times 4$ Latin square with $28 \mathrm{~d}$ experimental periods, and it took place from October 2011 to February 2012. The William's experimental design (Williams, 1949) was used to generate a uniform design balanced for potential carry-over effects between treatments, as every treatment was fed in every period and to each pen, but never in the same sequence among pens.

All cows were cared for relative to applicable laws of the state of California and the USA, consistent with requirements for "The care and use of animals for scientific purposes", as per the South African National Standard (SANS 10386-2008).

\subsection{Farm and management}

The commercial dairy farm selected for this study is located near Hanford (CA, USA) and milks 5000 Holstein cows three times a day starting at 04:00, 12:00 and 20:00 h. Cows were housed in free stall barns, bedded with dried manure solids, with access to an outside dry lot and had fresh water available ad libitum. As per normal farm practices, cows were randomly allocated once a week from a single fresh pen at $\sim 20$ days in milk (DIM) to one of the four early lactation pens. Each of the four pens housed 320 multiparity early lactation cows (i.e., those cows which had cleared the fresh pen but were not yet confirmed pregnant) with similar lactation characteristics. Once confirmed pregnant, cows are moved from these pens to mid lactation pens. Normal cow movement in and out of the lactation pens was minimally restricted by the study. Treatments were randomly allocated to one of the four early lactation pens at the start of the 1st period and rotated after each $28 \mathrm{~d}$ experimental period as described above for a William's design.

\subsection{Diets}

The four rations were formulated by the farm nutritionist to be iso-nutritious for $\mathrm{CP}$ and fat, thus allowing comparison of CM and HPDDG as protein sources without confounding treatment effects with other diet nutrient changes, especially dietary fat levels. Treatments were created by varying the ratio of CM and HPDDG added to the diet at $200 \mathrm{~g} / \mathrm{kg}$ TMR dry matter (DM), while the other $800 \mathrm{~g} / \mathrm{kg}$ remained the same among treatments. On a DM basis, treatments were designed to be: (1) $0 \mathrm{~g} / \mathrm{kg} \mathrm{CM}$ and $200 \mathrm{~g} / \mathrm{kg}$ HPDDG, (2) $65 \mathrm{~g} / \mathrm{kg} \mathrm{CM}$ and $135 \mathrm{~g} / \mathrm{kg}$ HPDDG, (3) $135 \mathrm{~g} / \mathrm{kg} \mathrm{CM} \mathrm{and} 65 \mathrm{~g} / \mathrm{kg}$ HPDDG, (4) 200 g/kg $\mathrm{CM}$ and $0 \mathrm{~g} / \mathrm{kg}$ HPDDG.

Cows were fed a TMR which was prepared immediately before each feeding by mixing the individual ingredients (i.e., alfalfa hay, wheat and corn silages, CM, HPDDG) and a premix containing the dry ingredients (i.e., almond hulls, oat hay, steam flaked corn grain, cracked pima cottonseed, liquid molasses, mineral premix) in a conventional 2 screw vertical mixer. Cows were fed each morning between 04:30 and 07:30 h, while the cows were at morning milking, and again between 11:00 and $12: 30 \mathrm{~h}$ for ad libitum intake. Each pen received a total of $\sim 15,500 \mathrm{~kg}$ of as mixed TMR/d, split into 2 loads (i.e., one full $8500 \mathrm{~kg}$ load of TMR at $1 \mathrm{st}$ feeding with a second $\sim 7000 \mathrm{~kg}$ load of TMR at 2 nd feeding with the exact amount determined by the feeder). Each 1st feeding of TMR was fed to a clean bunk as bunks were cleared of all residual feed, which was weighed daily by pen, immediately prior to the 1st feeding. Weights for each load of TMR fed were recorded on record sheets at the time of feeding and used together with daily refusals to calculate DM intake per cow/pen. The "TMR tracker" system (Digi-Star LLC, Fort Atkinson, WI, USA) kept a record of the actual ingredient profiles of each batch of TMR mixed.

\subsection{Sample collection, preparation and analytical methods}

\subsubsection{Total mixed rations and ingredients}

Individual feed ingredients and TMR were sampled twice during the last $7 \mathrm{~d}$ (i.e., the sampling week) of each of the 4 experimental periods. Ingredients were pooled by period for chemical analysis. Ten handfuls of each TMR were collected at evenly spaced intervals at pre-marked posts along the bunk-line according to Robinson and Meyer (2010) immediately after feeding and before the cows had access to it. All TMR samples, silages and other wet ingredients were weighed, dried 
at $55^{\circ} \mathrm{C}$ for $48 \mathrm{~h}$, and allowed to air equilibrate at room temperature for $24 \mathrm{~h}$ in order to create moisture stable samples to facilitate determination of their air DM content, before being sent for chemical analysis to the UC Davis service laboratory. All samples were ground to pass a $1 \mathrm{~mm}$ screen on a model 4 Wiley Mill (Thomas Scientific, Swedesboro, NJ, USA). Oven DM was determined as the gravimetric loss when dried at $105^{\circ} \mathrm{C}$ for $2 \mathrm{~h}$ in a forced air oven (Reuter et al., 1986). Total $\mathrm{N}$ and acid detergent insoluble CP (ADICP) were determined by the Leco method (Method 990.03, AOAC, 1997) while acid detergent fiber (ADF) and lignin treated with sulphuric acid (lignin(sa)) were determined according to the method 973.18 of AOAC (1997). The neutral detergent fiber (NDF) was determined as described by Van Soest et al. (1991). Heat stable amylase was added to samples with a high starch content to prevent filtering difficulties (i.e., aNDF) while aNDFom values do not include residual ash. Ash determination was based on gravimetric loss by heating samples to $550^{\circ} \mathrm{C}$ for $8 \mathrm{~h}$. Soluble carbohydrates (i.e., free sugars fructose, glucose, sucrose) were determined by high performance liquid chromatography as described by Johansen et al. (1996). Minerals were determined using methods of Johnson and Ulrich (1959), Tracy and Moeller (1990) and Meyer and Keliher (1992). Fat was quantified using a standard Soxhlet extraction (Method 2003.05, AOAC, 2006).

\subsubsection{Animal measurements}

At the start of the study, a group of $\sim 180$ cows with the lowest DIM (i.e., 30 to 88 DIM) were selected from each pen and coded in DairyComp 305 (DC305, Valley Agricultural Software, Tulare, CA, USA), in order to prevent them from being sold or moved unless necessary for health purposes. Due to their low DIM, these cows were the most likely to complete the study in their originally assigned pen. This group of $\sim 180$ cows/pen was used as the base group from which all representative subgroups were selected for animal samples (i.e., urine, blood) and measurements (i.e., girth, body scores). Only milk production and composition data used all cows which remained eligible (i.e., in their originally assigned pen) throughout the study, regardless of their DIM at the start of the study.

Weekly data backups of the DC305 herd record system were made to crosscheck cow movements. For a cow to remain eligible (i.e., to be included in any sampling dataset and the resulting statistical analysis), they had to have been in their originally assigned pen for the entire $16 \mathrm{wk}$. study (i.e., any movement of a cow from their originally assigned pen to another pen, such as the hospital pen, precluded their eligibility. Cows to be sampled or measured (as described in the previous paragraph) were identified by ear tag number during the routine $60 \mathrm{~min}$ 'lockup' which occurred every morning, immediately after milking, for normal pregnancy diagnosis and artificial insemination.

2.3.2.1. Milk production and composition. Milk samples were collected, and milk yields recorded, during the first milking (04:00-08:00 h) for all four pens on day 28 of each experimental period by Dairy Herd Improvement Association (DHIA) personnel. Daily milk production was estimated by multiplying the recorded yield by three. A small representative subsample of milk was drawn from the sample collection flask (after a short period of mixing) of all cows and preserved with a 2-bromo-nitropropane-1,3-diol preservative for subsequent analytical testing. Fat, true protein, lactose and somatic cell counts (SCC) were determined using near infrared spectroscopy at the DHIA laboratory in Hanford (CA, USA).

2.3.2.2. Body condition score. A representative subgroup of $\sim 140$ cows/pen was selected from the base group of $\sim 180$ cows/pen (see Section 2.3.2) at the start of the study for body condition scoring (BCS). This was completed by the same trained scorer on the first day of period 1 and at the end of the sampling week of each experimental period. The BCS system of Ferguson et al. (1994) was used, which works on quarter points based upon several anatomical characteristics of the cows. However, when a cow demonstrated characteristics which made it difficult to clearly classify her to a specific quarter point (e.g., either 2.00 versus 2.25), she was classed as being intermediate (i.e., 2.125). This resulted in addition of an additional 8th point to the system of Ferguson et al. (1994).

2.3.2.3. Urine. Spot urine samples were collected on one day during the sampling week of each experimental period from the first $\sim 35$ cows from the base group of $\sim 180$ cows/pen which voluntarily urinated during morning lockup. Aliquots of urine $(7 \mathrm{ml})$ were transferred into tubes containing $2 \mathrm{ml}$ of $100 \mathrm{ml} / \mathrm{L}$ sulphuric acid, reducing the final pH $<2$ to prevent bacterial destruction of allantoin (AL) and diluted with deionized water (to prevent precipitation of uric acid) to a final volume of $35 \mathrm{ml}$ and frozen at $-20^{\circ} \mathrm{C}$. Urine samples were chemically analyzed for creatinine (CR) at the Animal Health Diagnostic Center (College of Veterinary Medicine, Cornell University, Ithaca, NY, USA) according to the Jaffé method using a urine creatinine kit (Roche Diagnostics Corporation, Indianapolis, IN, USA) which utilizes a kinetic colorimetric assay during which CR forms a yellow-orange complex with picrate. Analysis for AL was according to Chen and Gomes (1992), which is based on the method of Young and Conway (1942). Standards were prepared to create working concentrations of 20, 40, 60, 80 and 100 mg/L AL. Urine samples were thawed and centrifuged at $1200 \times \mathrm{g}$ for $15 \mathrm{~min}$ at $20-22^{\circ} \mathrm{C}$ in order to remove precipitate which could influence the colorimetric reading. Samples were diluted 60 times to fit the standard curve. A duplicate standard curve was included at the start and end of each run in order to calculate the AL concentrations in the urine samples. Two inter-run standard samples were used in each run to assess variation among runs but, as all inter-run standards were within 0.05 of the average over all runs, all runs were accepted without inter-run correction. Each urine sample was analyzed in duplicate with the average used as the final concentration.

2.3.2.4. Girth measurements. The group of $\sim 35$ cows/pen from which urine had been collected in each period were girth measured the next morning using a weigh tape measure (The Coburn company, Inc., Whitewater, WI, USA), by placing the 
tape around the girth of each cow, just behind the front legs, making sure it was straight and snug and the cow was relaxed before the reading was made.

2.3.2.5. Blood plasma. A smaller subgroup of 24 cows/pen was selected from the base group of $\sim 180 /$ pen for blood sampling. Blood was collected from the tail (coccygeal) vein of each cow using a $10 \mathrm{ml}$ evacuated tube containing $\mathrm{K}_{2}$ EDTA(Vacutainer, Becton Dickinson, Franklin Lakes, NJ, USA), kept in coolers with ice and centrifuged immediately at $2100 \times \mathrm{g}$ for $15 \mathrm{~min}$ at $4{ }^{\circ} \mathrm{C}$. Plasma was removed, transferred to duplicate Eppendorf tubes and frozen at $-20^{\circ} \mathrm{C}$. Samples were sent to the Molecular Structure Facility (University of California, Davis, CA, USA) for physiological AA (i.e., free plasma AA) and ammonia analysis. After samples were acidified with sulfosalicyclic acid to precipitate intact proteins, AA were quantified using a Beckman 6300 AA analyzer (Beckman Coulter, Inc., La Brea, CA, USA) utilizing a lithium citrate buffer system and ion-exchange chromatography to separate AA followed by a "post-column" ninhydrin reaction detection system. Blood urea N (BUN) was measured on the same set at the Animal Health Diagnostic Center (College of Veterinary Medicine, Cornell University, Ithaca, NY, USA), utilizing an automated Roche Modular P Chemistry Analyzer (Roche Diagnostics, Indianapolis, IN, USA).

\subsection{Calculations}

Final oven DM was calculated as the air equilibrated DM (i.e., dried at $55^{\circ} \mathrm{C}$ ) multiplied by the lab oven DM (i.e., dried at $\left.105^{\circ} \mathrm{C}\right)$.

Milk energy content ( $\mathrm{MJ} / \mathrm{kg}$ ) was calculated using a prediction equation from Tyrell and Reid (1965), summing the energetic weights of the milk components as:

$$
\left(\frac{([(4.163 \times \text { fat }(\mathrm{g} / \mathrm{kg}))+(2.413 \times(\mathrm{TP}(\mathrm{g} / \mathrm{kg}) / 0.94))+(2.16 \times \text { lactose }(\mathrm{g} / \mathrm{kg}))]-11.72) \times 2.204}{1000}\right) \times 4.184
$$

with the factor 1000 converting kcal to Mcal, 2.204 converting Mcal $/ \mathrm{lb}$ to Mcal $/ \mathrm{kg}$ and 4.184 converting Mcal $/ \mathrm{kg}$ to $\mathrm{MJ} / \mathrm{kg}$. True protein (TP) was converted to $\mathrm{CP}$ assuming $60 \mathrm{~g} / \mathrm{kg}$ non-protein $\mathrm{N}$ in total milk $\mathrm{N}$.

Milk energy output $(\mathrm{MJ} / \mathrm{d})$ was calculated by multiplying milk energy content $(\mathrm{MJ} / \mathrm{kg}$ ) by daily milk yield ( $\mathrm{kg} / \mathrm{d})$.

Body weight (BW) was calculated using the prediction equation of Mäntysaari and Mäntysaari (2008) in which both heart girth measurements and BCS are considered when estimating BW $(\mathrm{kg})$ as:

$$
93.3+(230.882 \times \operatorname{Girth}(\mathrm{m}))-(239.66 \times \mathrm{BCS})+(138.318 \times(\operatorname{Girth}(\mathrm{m}) \times \mathrm{BCS}))
$$

A partial net energy output (MJ/d) balance, used to determine where consumed energy was utilized among the treatments, was calculated by summing the maintenance (NRC, 2001), milk and BCS change energy where maintenance energy (MJ/d) was calculated using BW $(\mathrm{kg})$ as:

$$
\left(\mathrm{BW}^{0.75} \times 0.08\right) \times 4.184
$$

and BCS change was calculated as the difference between the BCS at the end and at the beginning of each period and BCS change energy $(\mathrm{MJ} / \mathrm{d})$ was calculated as:

$$
\left(\frac{\text { BCS change } \times 300}{28}\right) \times 4.184
$$

assuming 1 unit BCS change over $28 \mathrm{~d}=300 \mathrm{Mcal} \mathrm{NE}_{\mathrm{L}}$ (Chilliard et al., 1991) with the factor $4.184 \mathrm{converting} \mathrm{Mcal} / \mathrm{d}$ to $\mathrm{MJ} / \mathrm{d}$.

Net energy for lactation $\left(\mathrm{NE}_{\mathrm{L}}\right)$ density $(\mathrm{MJ} / \mathrm{kg} \mathrm{DM})$ of the rations was estimated using the biological responses of the animals, as expressed in the partial net energy output, and measured DM intake as:

$$
\frac{\text { Net energy output }(\mathrm{MJ} / \mathrm{d})}{\text { DM intake }(\mathrm{kg} / \mathrm{d})}
$$

\subsection{Statistical analysis}

All cows which moved from their originally assigned pen during the study, for health or any other reason, were excluded from statistical analysis, thereby reducing the number of eligible cows in each response parameter subgroup from the starting numbers. This resulted in 533 out of 1282 starting cows being eligible for statistical analysis of milk production and 308 out of 560 (i.e., 140 cows/pen) starting cows being eligible for the BCS dataset. Outlier analysis completed blind to treatments identified 10 cows which were removed from the milk production dataset (i.e., 1 due to missing milk composition values in period 4, 1 cow for a milk fat level $>65 \mathrm{~g} / \mathrm{kg}, 4$ cows for a milk production $<18 \mathrm{~kg} / \mathrm{d}$ and 4 cows for SCC $>4000,000 \mathrm{cfu}$ (which was above the assay range)), and 5 cows which were removed from the BCS dataset due to abnormally high or low values. This resulted in final sets of 523, 303 and 346 cows being included in the statistical analysis for milk production, BCS and girth measurements respectively. From the group of 77 eligible blood cows, 16 (i.e., 4/pen) were randomly selected for plasma AA and BUN assays and 40 cows (i.e., 10/pen) were randomly selected from the group of 346 eligible urine cows for urine AL and CR assays. 
Animal production, BCS, girth measurements, urine AL, urine CR, plasma AA and BUN levels were analyzed using the MIXED procedure of SAS (2000) for a $4 \times 4$ Latin square design, with cow as the experimental unit within pen in the random statement and period, pen and treatment as fixed effects, which is consistent with guidelines of this journal (Robinson et al., 2006). Orthogonal polynomial contrasts were used in SAS to test linear and quadratic effects of the CM and HPDDG inclusion levels. Second order polynomial regressions were fitted to milk production, milk component, and BCS data in order to depict treatment responses, and the regression equations were used to determine maximum response points.

Dry matter intake ( $n=4$ pens, calculated on a pen basis with 4 pens/period), TMR components and ingredients and net energy balance ( $n=4$ pens) used pen as the experimental unit in the GLM option of SAS (2000) with period, pen and treatment as fixed effects.

Reported values are least squares means with differences accepted as significant if $\mathrm{P} \leq 0.01$ and trends at $\mathrm{P} \leq 0.05$.

\section{Results}

\subsection{Ration evaluation}

The chemical composition of the ingredients used in the TMR (Table 1) was similar to ingredients as listed in NRC (2001). Analysis of HPDDG showed that it had a much higher CP (395 versus $300 \mathrm{~g} / \mathrm{kg}$ ) but lower fat (54.5 versus $113 \mathrm{~g} / \mathrm{kg}$ ) content than conventional DDGS. However, HPDDG was similar to CM for both the CP (395 versus $410 \mathrm{~g} / \mathrm{kg}$ ) and fat (55 versus $26 \mathrm{~g} / \mathrm{kg}$ ) content.

The ingredient profile of the TMR fed (Table 2) did not differ among treatments, except for inclusion of CM and HPDDG, which varied among treatments as per the experimental objective. While there were small substitutions of minor byproducts (i.e., pomegranate, whey, citrus, potatoes) among periods, these changes made up a very small proportion of the total ration $(57 \mathrm{~g} / \mathrm{kg})$ and were the same among treatments. There were no differences in the DM, CP, fat and starch content of the TMR among treatments, confirming that the dietary objective of iso-proximate nutrient rations was achieved. Linear differences in the nutrient composition among treatments, especially in organic matter (OM), sugar, ADICP and some macro- and micro-minerals were consistent with the difference in CM versus HPDDG inclusion, but none were judged to be biologically relevant. The NDF level decreased slightly with higher CM inclusion levels, due to the higher relative fiber level of HPDDG. However, these differences were numerically small and not considered to be biologically significant. The TMR met all nutrient requirements of lactating dairy cows producing 45-50 L milk/d (NRC, 2001).

\subsection{Animal measurements}

\subsubsection{Milk production and composition}

Milk production (Table 3) had a linear and quadratic response, increasing at a decreasing rate with higher CM/HPDDG ratios, reaching a maximum of $47.88 \mathrm{~kg} / \mathrm{d}$ at $135 \mathrm{~g} / \mathrm{kg}$ CM inclusion before decreasing slightly. Both milk TP content and yield responded quadratically $(\mathrm{P}<0.01$ ) to the higher $\mathrm{CM} /$ HPDDG ratio. However, while TP yield followed the pattern of milk yield with a fitted maximum of $1.4 \mathrm{~kg} / \mathrm{d}$ at $135 \mathrm{~g} / \mathrm{kg} \mathrm{CM}$ inclusion (Fig. 1), the fitted maximum TP content of $29.4 \mathrm{~g} / \mathrm{kg}$ was at a level of $120 \mathrm{~g} / \mathrm{kg} \mathrm{CM}$ inclusion (Fig. 1). Milk fat content decreased linearly with higher CM inclusions, even though only to a small extent, while milk fat yield responded quadratically $(\mathrm{P}<0.01)$. However, even with this decrease in fat content, the fitted maximum fat yield of $1.64 \mathrm{~kg} / \mathrm{d}$ was still at $\sim 110 \mathrm{~g} / \mathrm{kg} \mathrm{CM} \mathrm{(Fig.} \mathrm{1),} \mathrm{mainly} \mathrm{due} \mathrm{to} \mathrm{the} \mathrm{higher} \mathrm{milk} \mathrm{productions} \mathrm{at} \mathrm{higher} \mathrm{CM} \mathrm{lev-}$ els. Milk energy content followed fat content with a linear decrease as CM inclusion increased. However, milk energy output had a similar quadratic and linear response $(\mathrm{P}<0.01$ ) as milk yield with a peak of $136 \mathrm{MJ} /$ day at $120 \mathrm{~g} / \mathrm{kg} \mathrm{CM} \mathrm{inclusion} \mathrm{(Fig.} 1$ ).

\subsubsection{Body condition score}

Body condition score (Table 3) was not affected by treatments, but the mean BCS of 2.37 was slightly below the desired range for most efficient milk production of 2.5-3.0 (Wildman et al., 1982; Wattiaux, 1994). Change in BCS over 28 d was positive for all treatments, which is desirable for cows post peak production, while suggesting that the additional milk at the $135 \mathrm{~g} / \mathrm{kg}$ CM inclusion level was not produced at the expense of body condition. The best fitted line (Fig. 1) showed a quadratic response with a fitted maximum BCS gain of 0.063 units $/ 28 \mathrm{~d}$ at $\sim 120 \mathrm{~g} / \mathrm{kg} \mathrm{CM}$ inclusion. Energy used for BCS change (Table 6 ) also had a quadratic response, with the highest energy need of $2.85 \mathrm{MJ} / \mathrm{d}$ at $\sim 120 \mathrm{~g} / \mathrm{kg} \mathrm{CM}$ inclusion (Fig. 1 ).

\subsubsection{Urine}

Urine AL concentrations (Table 4 ) did not differ among treatments while CR concentrations decreased linearly ( $\mathrm{P}=0.01$ ) with higher CM inclusions, which could be due to increased urine volume. However, since total urine was not collected, the ratio of $A L$ to $C R$ was used to estimate the change in rumen microbial growth. The AL:CR ratio increased $(P<0.01)$ with higher $\mathrm{CM}$ inclusion levels.

\subsubsection{Blood plasma}

All essential amino acids (EAA) except histidine $(\mathrm{P}=0.80)$ responded linearly, with threonine and histidine also responding quadratically, to an increased CM/HPDDG ratio in the diet (Table 5; $<<0.01$ ). By increasing, or decreasing, in the plasma as the ratio of the two ingredients in the ration changed, the impacts of the differences in the AA profiles of CM and HPDDG 
Table 2

Ingredient profile and chemical composition ( $\mathrm{g} / \mathrm{kg}$ dry matter) of total mixed rations fed to cows.

\begin{tabular}{|c|c|c|c|c|c|c|}
\hline & \multicolumn{4}{|c|}{$\mathrm{g} / \mathrm{kg}$ DM canola meal in the ration } & \multirow[t]{2}{*}{ SEM } & \multirow{2}{*}{$\begin{array}{c}\mathrm{P}^{*} \\
\text { Linear }\end{array}$} \\
\hline & $0 \mathrm{~g} / \mathrm{kg}$ & $65 \mathrm{~g} / \mathrm{kg}$ & $135 \mathrm{~g} / \mathrm{kg}$ & $200 \mathrm{~g} / \mathrm{kg}$ & & \\
\hline \multicolumn{7}{|l|}{ Ingredient profile, $\mathrm{g} / \mathrm{kg} D M^{\mathrm{a}}$} \\
\hline \multicolumn{7}{|l|}{ Premix } \\
\hline Almond, hulls & 96.4 & 96.9 & 96.5 & 97.3 & 2.37 & 0.82 \\
\hline Oat, hay & 23.5 & 23.6 & 23.5 & 23.7 & 0.32 & 0.68 \\
\hline Corn, steam flaked grain & 161 & 162 & 161 & 163 & 7.9 & 0.91 \\
\hline Mineral, premix & 16.4 & 16.5 & 16.4 & 16.6 & 1.16 & 0.94 \\
\hline Fat, rumen inert ${ }^{\mathrm{b}}$ & 12.8 & 12.9 & 12.9 & 13.0 & 0.15 & 0.65 \\
\hline Cottonseed, cracked Pima ${ }^{c}$ & 72.2 & 72.6 & 72.2 & 72.8 & 0.46 & 0.39 \\
\hline Molasses, liquid & 11.4 & 11.5 & 11.4 & 11.5 & 0.11 & 0.58 \\
\hline Canola meal, pellets (solvent) & 0.00 & 66.1 & 135 & 199 & 0.86 & $<0.01$ \\
\hline HPDDG $^{\mathrm{d}}$ & 202 & 136 & 67.9 & 0.00 & 0.83 & $<0.01$ \\
\hline Wheat, silage & 42.4 & 43.1 & 42.5 & 41.9 & 1.00 & 0.59 \\
\hline Corn, silage & 214 & 213 & 214 & 216 & 6.0 & 0.78 \\
\hline Other ${ }^{\mathrm{e}}$ & 56.7 & 56.4 & 56.1 & 56.7 & 4.83 & 0.99 \\
\hline Dry matter & 521 & 519 & 518 & 509 & 20.6 & 0.53 \\
\hline Organic matter & 927 & 925 & 922 & 918 & 2.6 & $<0.01$ \\
\hline Crude protein & 170 & 170 & 167 & 170 & 3.8 & 0.72 \\
\hline ADICPg & 96.9 & 90.2 & 82.0 & 71.2 & 9.44 & $<0.01$ \\
\hline $\mathrm{aNDF}^{\mathrm{h}}$ & 334 & 321 & 321 & 308 & 7.9 & $<0.01$ \\
\hline aNDFom $^{\mathrm{i}}$ & 324 & 311 & 312 & 299 & 7.3 & $<0.01$ \\
\hline $\mathrm{ADF}^{j}$ & 214 & 220 & 221 & 217 & 6.7 & 0.60 \\
\hline Fat & 53.8 & 53.7 & 53.5 & 53.0 & 2.04 & 0.67 \\
\hline $\operatorname{Lignin}(s a)^{\mathrm{k}}$ & 42.8 & 46.0 & 47.8 & 50.0 & 2.47 & $<0.01$ \\
\hline Starch & 188 & 192 & 202 & 190 & 7.6 & 0.47 \\
\hline Sugars & 33.8 & 38.8 & 40.5 & 47.5 & 3.31 & $<0.01$ \\
\hline $\mathrm{Ca}$ & 7.84 & 8.27 & 8.51 & 9.25 & 0.451 & $<0.01$ \\
\hline $\mathrm{P}$ & 3.37 & 3.76 & 4.17 & 4.59 & 0.246 & $<0.01$ \\
\hline K & 14.7 & 15.6 & 16.2 & 16.8 & 0.55 & $<0.01$ \\
\hline $\mathrm{Mg}$ & 2.32 & 2.58 & 2.80 & 3.14 & 0.084 & $<0.01$ \\
\hline S & 2.47 & 2.50 & 2.53 & 2.62 & 0.064 & 0.01 \\
\hline \multicolumn{7}{|l|}{$m g / k g D M$} \\
\hline $\mathrm{Zn}$ & 75.9 & 76.4 & 76.0 & 79.7 & 3.04 & 0.20 \\
\hline Mn & 32.3 & 35.7 & 39.3 & 43.7 & 12.44 & $<0.01$ \\
\hline $\mathrm{Fe}$ & 209 & 195 & 194 & 186 & 16.8 & 0.14 \\
\hline $\mathrm{Cu}$ & 14.8 & 15.0 & 14.5 & 15.1 & 0.81 & 0.88 \\
\hline Mo & 1.11 & 1.09 & 1.13 & 1.14 & 0.083 & 0.55 \\
\hline Se & 0.29 & 0.30 & 0.36 & 0.40 & 0.016 & $<0.01$ \\
\hline
\end{tabular}

a Samples pooled by period ( $n=2$ per period), based on average ingredient composition during sampling week for each pen, each period (i.e., 16 total samples).

b EnerGII. Virtus Nutrition, LLC. 520 Industrial Way, Corcoran, CA, USA.

c Fuzzy upland cottonseed in period 1 .

d High protein, low fat, dried distillers grains (see Table 1).

e Period 1: Pomegranate waste and whey liquid (60:40). Period 2: Citrus pulp and pomegranate waste (40:60). Periods 3 and 4: Citrus pulp and potatoes (50:50) and (60:40)

$\mathrm{f}$ Based on total mixed ration samples collected twice during sampling week for each pen, each period (i.e., 32 total samples).

$\mathrm{g}$ Acid detergent insoluble crude protein ( $\mathrm{g} / \mathrm{kg}$ of crude protein).

h Neutral detergent fiber assayed with heat stable amylase, expressed inclusive of residual ash.

${ }^{i}$ Neutral detergent fiber assayed with heat stable amylase, expressed exclusive of residual ash.

j Acid detergent fiber, expressed inclusive of residual ash.

k Lignin determined by solubilization of cellulose with sulphuric acid.

* No quadratic effect reached statistical significance (i.e., $\mathrm{P}>0.08$ ).

were demonstrated. Most of the EAA increased slightly between 0 and $65 \mathrm{~g} / \mathrm{kg} \mathrm{CM}$, increasing at a faster rate from 65 to $135 \mathrm{~g} / \mathrm{kg}$ CM before plateauing at $200 \mathrm{~g} / \mathrm{kg}$ CM. Threonine and arginine kept increasing linearly from 65 to $200 \mathrm{~g} / \mathrm{kg} \mathrm{CM}$. Leucine and phenylalanine decreased linearly with higher CM levels while methionine and histidine decreased from 0 to $65 \mathrm{~g} / \mathrm{kg} \mathrm{CM}$, remained constant up to $165 \mathrm{~g} / \mathrm{kg}$ CM before increasing slightly at $200 \mathrm{~g} / \mathrm{kg}$ CM. The plasma lysine to methionine ratio increased with higher CM levels, with the optimum ratio of 3:1 (NRC, 2001) achieved between 65 and $135 \mathrm{~g} / \mathrm{kg}$ CM.

\subsubsection{Partial net energy balance}

Pen averages of response parameters per period were used to calculate the partial NE balance (Table 6) for each treatment. Calculated milk and total energy output changed quadratically with increasing CM inclusion levels (i.e., highest values at 
Table 3

Production performance and body measurements for cows fed rations with different levels of canola meal and HPDDG.

\begin{tabular}{|c|c|c|c|c|c|c|c|}
\hline & \multicolumn{4}{|c|}{$\mathrm{g} / \mathrm{kg}$ DM canola meal in the ration } & \multirow[t]{2}{*}{ SEM } & \multicolumn{2}{|c|}{$\mathrm{P}$} \\
\hline & $0 \mathrm{~g} / \mathrm{kg}$ & $65 \mathrm{~g} / \mathrm{kg}$ & $135 \mathrm{~g} / \mathrm{kg}$ & $200 \mathrm{~g} / \mathrm{kg}$ & & Linear & Quadratic \\
\hline \multicolumn{8}{|l|}{$n=4$ pens } \\
\hline \multicolumn{8}{|l|}{$n=523$ cows } \\
\hline \multicolumn{8}{|l|}{ Yield (kg/d) } \\
\hline Milk & 44.94 & 47.41 & 47.88 & 47.35 & 0.335 & $<0.01$ & $<0.01$ \\
\hline Fat & 1.56 & 1.64 & 1.63 & 1.59 & 0.015 & 0.26 & $<0.01$ \\
\hline True protein & 1.30 & 1.39 & 1.40 & 1.38 & 0.009 & $<0.01$ & $<0.01$ \\
\hline Lactose & 2.16 & 2.27 & 2.27 & 2.24 & 0.016 & $<0.01$ & $<0.01$ \\
\hline Energy output (MJ/d) & 129.1 & 136.1 & 135.7 & 133.2 & 0.95 & $<0.01$ & $<0.01$ \\
\hline \multicolumn{8}{|l|}{ Components (g/kg) } \\
\hline Fat & 34.8 & 34.8 & 34.1 & 33.7 & 0.24 & $<0.01$ & 0.23 \\
\hline True protein & 29.1 & 29.4 & 29.4 & 29.3 & 0.10 & 0.02 & $<0.01$ \\
\hline Lactose & 48.1 & 47.8 & 47.3 & 47.3 & 0.07 & $<0.01$ & $<0.01$ \\
\hline Energy density (MJ/kg) & 2.88 & 2.88 & 2.84 & 2.83 & 0.010 & $<0.01$ & 0.19 \\
\hline Body condition score (BCS) & 2.36 & 2.38 & 2.38 & 2.36 & 0.022 & 0.62 & 0.06 \\
\hline BCS change (unit/28 d) & 0.011 & 0.034 & 0.080 & 0.029 & 0.0143 & 0.11 & $<0.01$ \\
\hline \multicolumn{8}{|l|}{$n=346$ cows } \\
\hline Girth $(\mathrm{cm})$ & 205.7 & 205.3 & 205.8 & 205.5 & 0.47 & 0.98 & 0.55 \\
\hline Body weight (kg) & 673 & 674 & 675 & 671 & 3.5 & 0.81 & 0.44 \\
\hline
\end{tabular}

a High protein, low fat, dried distillers grains (see Table 1).
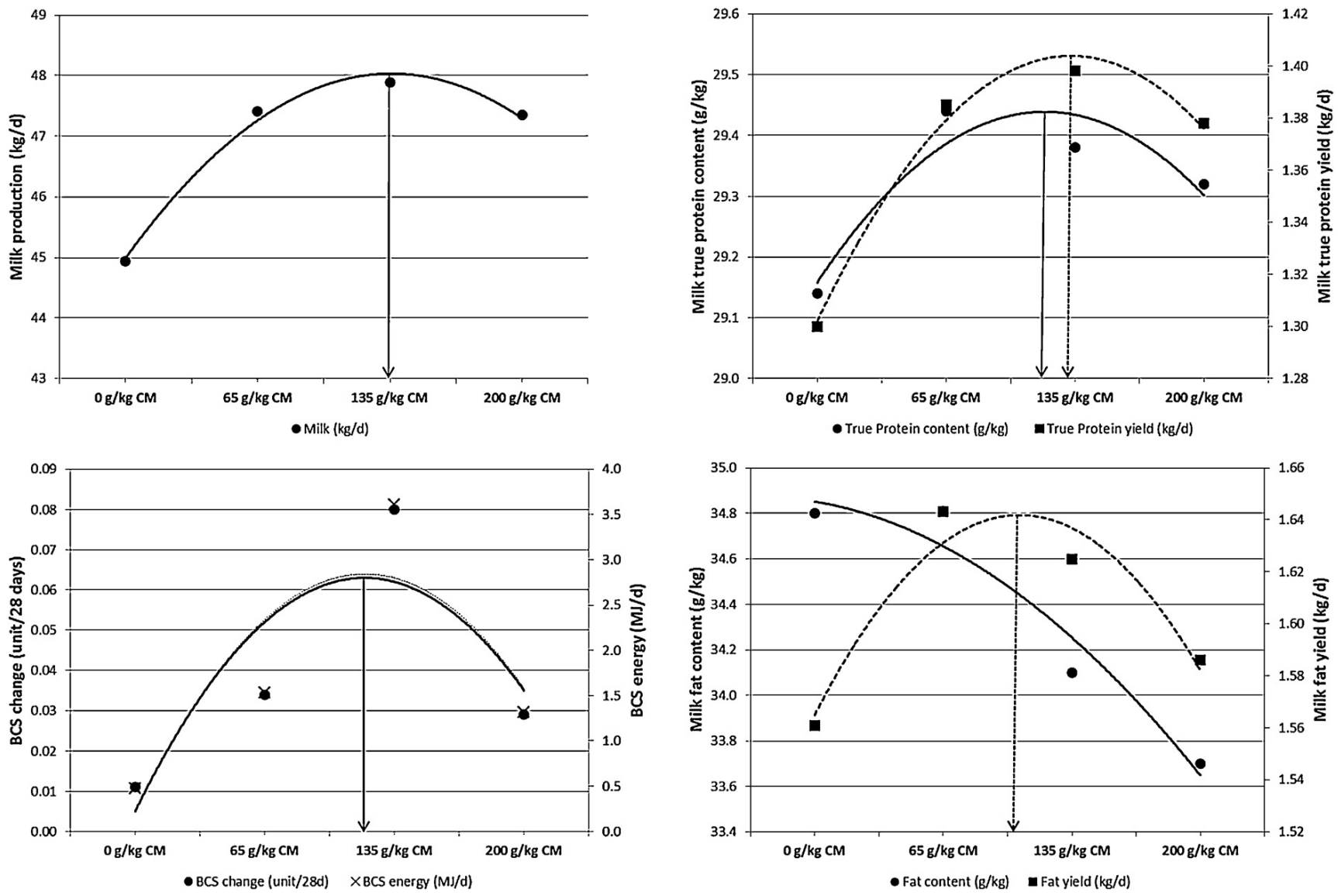

Fig. 1. Production and body condition data with polynomial regressions (to the 2 nd order) fitted to determine the maximum response treatment points. 
Table 4

Urine allantoin and creatinine concentrations $(\mathrm{mg} / \mathrm{L})$ for cows fed rations with different levels of canola meal and HPDDG. ${ }^{\mathrm{a}}$

\begin{tabular}{|c|c|c|c|c|c|c|c|}
\hline & \multicolumn{4}{|c|}{$\mathrm{g} / \mathrm{kg}$ DM canola meal in the ration } & \multirow[t]{2}{*}{ SEM } & \multicolumn{2}{|c|}{$\mathrm{P}$} \\
\hline & $0 \mathrm{~g} / \mathrm{kg}$ & $65 \mathrm{~g} / \mathrm{kg}$ & $135 \mathrm{~g} / \mathrm{kg}$ & $200 \mathrm{~g} / \mathrm{kg}$ & & Linear & Quadratic \\
\hline \multicolumn{8}{|l|}{$n=40 \operatorname{cows}^{\mathrm{c}}$} \\
\hline Allantoin (AL) & 3360 & 3187 & 3396 & 3370 & 97.9 & 0.57 & 0.43 \\
\hline Creatinine (CR) & 1082 & 980 & 1028 & 946 & 35.3 & 0.01 & 0.75 \\
\hline AL:CR ratio & 3.12 & 3.29 & 3.36 & 3.61 & 0.088 & $<0.01$ & 0.58 \\
\hline PDC index ${ }^{\mathrm{b}}$ & 640 & 672 & 690 & 737 & 17.1 & $<0.01$ & 0.65 \\
\hline
\end{tabular}

a High protein, low fat, dried distillers grains (see Table 1 ).

b Purine derivative to creatinine index $=\left(A_{2}\right.$ adjusted $\left.: C R\right) \times(\text { body weight }(\mathrm{kg}))^{0.75}$.

c Only a group of 10 cows/pen were selected from the group of eligible urine cows for urine AL and CR analysis as these were the cows with repeated samples across periods.

Table 5

Free amino acid and urea concentrations $(\mu \mathrm{g} / \mathrm{ml})$ in plasma of cows fed rations with different levels of canola meal and HPDDG. ${ }^{\mathrm{a}}$

\begin{tabular}{|c|c|c|c|c|c|c|c|}
\hline & \multicolumn{4}{|c|}{$\mathrm{g} / \mathrm{kg}$ DM canola meal in the ration } & \multirow[t]{2}{*}{ SEM } & \multicolumn{2}{|c|}{$\mathrm{P}$} \\
\hline & $0 \mathrm{~g} / \mathrm{kg}$ & $65 \mathrm{~g} / \mathrm{kg}$ & $135 \mathrm{~g} / \mathrm{kg}$ & $200 \mathrm{~g} / \mathrm{kg}$ & & Linear & Quadratic \\
\hline \multicolumn{8}{|l|}{$n=16 \operatorname{cows}^{\mathrm{b}}$} \\
\hline Threonine & 10.9 & 10.2 & 12.1 & 14.0 & 0.48 & $<0.01$ & $<0.01$ \\
\hline Valine & 30.4 & 30.6 & 33.3 & 34.4 & 1.00 & $<0.01$ & 0.42 \\
\hline Methionine & 3.89 & 3.42 & 3.38 & 3.48 & 0.132 & 0.03 & 0.03 \\
\hline Isoleucine & 14.3 & 14.2 & 15.9 & 16.5 & 0.51 & $<0.01$ & 0.30 \\
\hline Leucine & 36.1 & 31.4 & 28.5 & 23.0 & 1.08 & $<0.01$ & 0.64 \\
\hline Phenylalanine & 11.4 & 10.2 & 9.74 & 9.46 & 0.295 & $<0.01$ & 0.05 \\
\hline Tryptophan & 10.5 & 10.5 & 12.2 & 13.5 & 0.50 & $<0.01$ & 0.06 \\
\hline Lysine & 7.91 & 8.48 & 10.9 & 12.7 & 0.464 & $<0.01$ & 0.08 \\
\hline Histidine & 8.79 & 7.85 & 8.10 & 8.63 & 0.239 & 0.80 & $<0.01$ \\
\hline Arginine & 11.2 & 11.3 & 13.4 & 15.5 & 0.52 & $<0.01$ & 0.03 \\
\hline Lys:Met ratio & 2.11 & 2.59 & 3.33 & 3.73 & 0.146 & $<0.01$ & 0.67 \\
\hline \multicolumn{8}{|c|}{ Non-essential amino acids } \\
\hline Homocystine & 0.80 & 0.88 & 1.07 & 1.10 & 0.048 & $<0.01$ & 0.60 \\
\hline Tyrosine & 13.3 & 11.3 & 10.2 & 9.32 & 0.479 & $<0.01$ & 0.15 \\
\hline Serine & 10.1 & 8.34 & 8.66 & 9.29 & 0.336 & 0.12 & $<0.01$ \\
\hline Glutamic acid & 6.83 & 6.97 & 6.99 & 7.22 & 0.195 & 0.13 & 0.78 \\
\hline Glutamine & 54.3 & 51.8 & 50.5 & 50.4 & 2.03 & 0.15 & 0.55 \\
\hline Glycine & 24.0 & 21.2 & 23.9 & 27.7 & 1.40 & $<0.01$ & $<0.01$ \\
\hline Alanine & 21.9 & 19.6 & 21.7 & 23.4 & 0.76 & 0.03 & $<0.01$ \\
\hline 3-Methylhistidine & 1.10 & 1.05 & 0.86 & 0.87 & 0.083 & $<0.01$ & 0.60 \\
\hline Urea & 143 & 147 & 152 & 149 & 4.3 & 0.15 & 0.30 \\
\hline Ammonia & 2.40 & 2.28 & 2.25 & 2.19 & 0.083 & 0.06 & 0.68 \\
\hline
\end{tabular}

a High protein, low fat, dried distillers grains (see Table 1 ).

b Only a group of 4 cows/pen/period was randomly selected from the group of eligible blood cows and sent for amino acid analysis as this was sufficient to determine significant differences among treatments.

Table 6

Partial net energy balance for cows fed rations with different levels of canola meal and HPDDG. ${ }^{\mathrm{a}}$

\begin{tabular}{|c|c|c|c|c|c|c|c|}
\hline & \multicolumn{4}{|c|}{$\mathrm{g} / \mathrm{kg}$ DM canola meal in the ration } & \multirow[t]{2}{*}{ SEM } & \multicolumn{2}{|c|}{$\mathrm{P}$} \\
\hline & $0 \mathrm{~g} / \mathrm{kg}$ & $65 \mathrm{~g} / \mathrm{kg}$ & $135 \mathrm{~g} / \mathrm{kg}$ & $200 \mathrm{~g} / \mathrm{kg}$ & & Linear & Quadratic \\
\hline \multicolumn{8}{|l|}{$n=4$ pens } \\
\hline Milk energy output (MJ/d) & 129 & 136 & 135 & 133 & 1.1 & 0.16 & 0.04 \\
\hline $\mathrm{BCS}^{\mathrm{b}}$ energy $(\mathrm{MJ} / \mathrm{d})$ & 0.6 & 1.6 & 3.5 & 1.2 & 1.33 & 0.67 & 0.43 \\
\hline Total net energy (MJ/d) & 174 & 182 & 183 & 179 & 1.5 & 0.15 & 0.04 \\
\hline $\mathrm{NE}_{\mathrm{L}}{ }^{\mathrm{c}}(\mathrm{MJ} / \mathrm{kg} \mathrm{DM})$ & 6.93 & 7.16 & 7.09 & 7.12 & 0.134 & 0.60 & 0.61 \\
\hline
\end{tabular}

\footnotetext{
a High protein, low fat, dried distillers grains (see Table 1 ).

b Body condition score.

c Net energy available for lactation.
} 
intermediate $\mathrm{CM}$ inclusion levels). However, even though the total NE balance was highest at intermediate $\mathrm{CM}$ inclusion levels, the calculated dietary $\mathrm{NE}_{\mathrm{L}}$ values did not differ $(\mathrm{P}=0.6)$ between the treatments, suggesting that dietary energy was used more efficiently at intermediate $\mathrm{CM}$ inclusion levels.

\section{Discussion}

In the current study optimum levels of CM in the diet for BCS change and milk production overlapped in the range of 120-135 g/kg DM. This corresponds with Mulrooney et al. (2009) where numerical values for DM intake, milk yield and composition, BW and BCS were higher with higher inclusions of CM versus DDGS, especially at their $2 / 3 \mathrm{CM}$ treatment. Increasing or decreasing inclusion levels of CM from $135 \mathrm{~g} / \mathrm{kg}$ DM in our study resulted in a general decline in cow performance, except milk fat content which was higher with higher levels of HPDDG compared to CM, which is also consistent with conclusions of Mulrooney et al. (2009) and Christen et al. (2010). Concerns about possible milk fat depression at high levels of DDGS, due to excessive dietary corn oil inclusion levels, were avoided by using HPDDG. However, since milk fat content decreased linearly with increased CM inclusion, although there was no numerical difference between the 0 and $65 \mathrm{~g} / \mathrm{kg}$ inclusion levels, it is possible that the highest levels of HPDDG might have prevented further increases in milk fat content.

\subsection{Potential impacts of differences in dietary $C P$ profile}

The four treatment rations actually fed were evaluated post-experimentally using the metabolic model Shield (Robinson, 2009) which calculates potential over- or undersupply of nutrients and estimates potential nutritional limitations to performance. It was known that, even though the CP content is very similar between CM and HPDDG, they have very different rumen degradability and AA profiles, with CM being primarily an RDP source, high in lysine, while HPDDG is an RUP source which is low in lysine. Model evaluations confirmed this by indicating that the rations with the highest HPDDG inclusion were limiting in RDP at only 0.84 of requirement, which would have limited microbial protein (MCP) production for the $0 \mathrm{~g} / \mathrm{kg} \mathrm{CM}$ treatment. In contrast, the $200 \mathrm{~g} / \mathrm{kg}$ CM treatment was limiting in RUP at 0.62 of requirement, only supplying 0.86 of required absorbable protein (AP).

According to NRC (2001), a drop of dietary RDP below 95-105 g/kg DM may depress MCP production. In our study, predicted RDP levels were 84, 89, 95 and $103 \mathrm{~g} / \mathrm{kg}$ DM for the 0,65, 135 and $200 \mathrm{~g} / \mathrm{kg}$ CM treatments respectively. Boucher et al. (2007) reported a maximum response of MCP production when RDP was 100-108 g/kg DM, while MCP production decreased at $116 \mathrm{~g} / \mathrm{kg}$ DM, probably due to overproduction of ammonia. At $1330 \mathrm{~g} / \mathrm{d}$, soluble CP intake for the $0 \mathrm{~g} / \mathrm{kg} \mathrm{CM}$ treatment according to Shield was only 0.64 of the predicted optimum, and was below the optimum level of $1200 \mathrm{~g} / \mathrm{d}$ as suggested in a review by Robinson (1996). Since Robinson (1996) also reported a decline in bacterial N flow when rumen ammonia concentrations fell below $90 \mathrm{mg} / \mathrm{L}$, or exceeded $110 \mathrm{mg} / \mathrm{L}$, either due to negative feedback mechanisms or direct bacterial toxicity, predicted rumen ammonia levels in our study (i.e., 62, 80, 100 and $113 \mathrm{mg} / \mathrm{L}$ for the $0,65,135 \mathrm{and} 200 \mathrm{~g} / \mathrm{kg}$ $\mathrm{CM}$ treatments respectively) suggest that MCP production may have been limited at the $0 \mathrm{~g} / \mathrm{kg}$ CM treatment. However, rumen ammonia concentrations of 123 and $128 \mathrm{mg} / \mathrm{L}$ were reported to be optimal for rumen bacterial growth by Reynal and Broderick (2005) and Boucher et al. (2007) respectively. This suggests that RDP and ammonia could have been limiting MCP production in the rumen, thereby reducing performance of cows in the all HPDDG treatments. However, the possibility of an oversupply of RDP, and therefore ammonia toxicity, at $200 \mathrm{~g} / \mathrm{kg}$ CM does not seem to have occurred.

Previous studies have demonstrated that the urine purine derivative (PD) content can be effectively used as a non-invasive method to estimate intestinal flow of MCP from the rumen (Chen and Ørskov, 2003; Gonzalez-Ronquillo et al., 2003). Chen et al. (1995) concluded that the PD to CR ratio in spot urine samples correlates well with intestinal flow of microbial purines and can be used as a qualitative indicator of rumen MCP supply, independent of urine volume, thereby obviating the need for total urine collection. Even though it is accepted that CR is excreted at a constant rate on a BW basis, daily CR excretion is related to body protein mass turnover and therefore varies among cows and studies (19-29 mg/kg BW; Valadares et al., 1999; Moorby et al., 2006). Thus our estimation of differences in MCP yield from the rumen is limited to relative measurements. Nevertheless, concentrations of AL and CR in our study were 20-50\% higher than in these previous studies.

In Han et al. (1992), Gonzalez-Ronquillo et al. (2003) and Moorby et al. (2006), lower DM intake, digestibility and milk yield could have been responsible for lower MCP production, and therefore lower AL concentrations, while very high urine volumes diluted AL concentration (mg/L) in Valadares et al. (1999). However, when DM intake, milk yield and urine volumes similar to ours were reported (Vagnoni and Broderick, 1997; Reynal and Broderick, 2005), AL concentrations are consistent among studies. Our CR concentrations were corrected by a factor of 0.7 (based on our internal laboratory results) to adjust for loss of CR after acid treatment to stabilize urine samples, which could be one reason why it is higher than in previous studies. However, Chizzotti et al. (2008) reported that heavier animals have lower body protein content, and therefore lower urine CR outputs per unit BW. The average BW of the cows in our current study was higher (673 versus 627 and $560 \mathrm{~kg}$ from Moorby et al., 2006 and Gonzalez-Ronquillo et al., 2003 respectively), but the BCS was relatively lower than in these studies. Since lean animals with a lower BCS may have a higher urine CR concentration per unit BW, expressing CR values as a function of metabolic BW converges the CR values among studies.

As it has been reported that urinary AL makes up an almost constant molar proportion of total PD, uric acid was not analyzed in our study and AL concentrations in urine samples were corrected to total PD using a factor of 0.91 (Vagnoni and Broderick, 1997; Valadares et al., 1999; Gonzalez-Ronquillo et al., 2003; Reynal and Broderick, 2005; Moorby et al., 2006), 
which was used to determine the purine derivative to creatinine (PDC) index as described by Chen and Ørskov (2003), thereby correcting the PD:CR ratio for metabolic BW to allow comparison among cows. The PDC index (Table 4) follows the same pattern as the AL:CR ratio, increasing linearly $(\mathrm{P}<0.01)$ with higher $\mathrm{CM}$ inclusions, strongly suggesting that MCP yield was not negatively affected by the increasing level of RDP due to increasing levels of CM in the ration. This suggests that a high level of rumen ammonia did not limit microbial growth on the $200 \mathrm{~g} / \mathrm{kg}$ CM diet, which corresponds with Reynal and Broderick (2005) and Boucher et al. (2007). It seems clear that increased levels of CM, up to $200 \mathrm{~g} / \mathrm{kg}$ DM, continued to stimulate rumen MCP production.

\subsection{Potential impacts of differences in dietary $A A$ profile}

It is generally accepted that lysine is the AA required in the largest quantities for milk production in high producing dairy cows. It has also been identified, together with methionine, as the 1st or 2nd limiting AA in corn-based dairy rations (NRC, 2001). Originating from corn grain, HPDDG is low in lysine (NRC, 2001) and, since many contemporary US dairy rations are already high in corn products (Swanepoel et al., 2010), there is a strong possibility that lysine was limiting at the highest HPDDG inclusion level in our study.

Christen et al. (2010) concluded that HPDDG delivered a more desirable AA profile for casein production, thereby increasing the TP content in milk, with a number of EAA being less limiting in HPDDG compared to CM. However, the positive effect that adding HPDDG to the ration had on production only occurred up to $120 \mathrm{~g} / \mathrm{kg}$ CM inclusion, after which production was reduced. A systematic review of the impacts of metabolizable lysine and methionine levels on cow performance (Robinson, 2010) showed that increased levels of corn protein in dairy rations depressed the level of lysine in AP and that rations with over 0.35 of total ration $\mathrm{CP}$ coming from corn products are responsive to supplemental lysine due to its limitation. In the context of our study, for the two treatments with the highest HPDDG inclusion, the proportions of total CP coming from corn products were 0.51 and 0.66 , suggesting the possibility of a lysine deficit.

Plasma AA analysis (Table 5) showed that lysine concentrations increased linearly with higher CM inclusions, while plasma methionine decreased with higher CM inclusion, but only to the $135 \mathrm{~g} / \mathrm{kg}$ level. The sharp initial decline in methionine from 0 to $65 \mathrm{~g} / \mathrm{kg}$ CM suggests that lysine was the limiting AA in the all HPDDG ration, thereby leaving excess AA unused in plasma at $0 \mathrm{~g} / \mathrm{kg} \mathrm{CM}$ but, as more lysine was supplied with the $65 \mathrm{~g} / \mathrm{kg} \mathrm{CM}$ ration, both methionine and lysine were utilized and their levels in plasma declined. All other EAA followed the same general pattern, supporting the hypothesis of lysine being the limiting AA at the highest HPDDG level. Excess AA remained unutilized in blood until lysine was supplied with more CM at the $135 \mathrm{~g} / \mathrm{kg} \mathrm{CM}$ level, after which AA were utilized for production. Alleviation of the AA limitation and the subsequent decrease in levels of other AA in plasma corresponds with other studies (e.g., Piepenbrink et al., 1998). The reduction in lysine with the all HPDDG diet, together with the decrease in MCP production, resulted in a substantial reduction in lysine available for milk production, which likely explains the reduced performance for the all HPDDG treatment.

The reduced performance with the $200 \mathrm{~g} / \mathrm{kg}$ CM diet cannot be attributed to decreased MCP production since there was a linear increase in PD derived MCP production with increasing CM inclusion levels. Milk protein yield usually increases linearly with increased flow of MCP up to a point at which something other than the total amount of AP limits milk protein production (Vagnoni and Broderick, 1997). Even though MCP provides between 0.40 and 0.93 of total protein reaching the small intestine (Djouvinov and Todorov, 1994; Robinson, 1996), the limited amount of dietary RUP is usually characterized by a limitation of specific AA at the intestinal absorptive site. The only EAA which decreased in plasma with increasing levels of $\mathrm{CM}$ were methionine, phenylalanine and leucine. However, in contrast to leucine which decreased linearly, both methionine $(\mathrm{P}=0.03)$ and phenylalanine $(\mathrm{P}=0.05)$ responded quadratically (i.e., declined less rapidly) with higher $\mathrm{CM}$ inclusions, but only plasma methionine tended to increase from the 135 to $200 \mathrm{~g} / \mathrm{kg} \mathrm{CM}$ treatment. That leucine showed a huge quantitative decline in plasma, almost 0.50 , with no quadratic effect, suggests that leucine was supplied over its requirement in all rations. Christen et al. (2010) reported phenylalanine and leucine as the 3rd and 4th limiting AA in corn silage based rations when HPDDG and CM were fed. When methionine and lysine were added to a CM containing diet by Piepenbrink et al. (1998), thereby alleviating their limitation, it increased milk protein content while leucine and phenylalanine levels in the plasma decreased, suggesting phenylalanine and then leucine as the 3rd and 4th limiting AA. This is also in accordance with Mulrooney et al. (2009) who showed the same plasma AA pattern as in our study when CM versus DDGS was fed. Most studies comparing protein sources identify lysine as the first limiting AA (Piepenbrink et al., 1998; Mulrooney et al., 2009; Christen et al., 2010). However, these studies use extraction efficiencies (i.e., arteriovenous differences of AA levels in plasma after (venous) and before (arterial) the mammary gland as a proportion of AA in the plasma of coccygeal artery) to identify limiting AA and, since mammary uptake of lysine from the plasma usually exceeds its requirements for milk production (Lapierre et al., 2005; Rulquin and Pisulewski, 2006), we argue that it will always appear as 1st limiting (Nichols et al., 1998), regardless of ration fed. Thus if lysine is removed from the list of limiting AA in those studies, the only 3 remaining possibilities are methionine, phenylalanine and leucine.

A study in which methionine, lysine and branched-chain AA were infused (Appuhamy et al., 2011) reported that branchedchain AA promoted muscle protein synthesis with no additional milk protein response with infusion of leucine over methionine and lysine. Even though both lysine and leucine are taken up in excess of requirements, mainly to oxidize and synthesize other AA, Lapierre et al. (2009) suggested that excess uptake of lysine across the mammary gland was required to maintain milk protein production while leucine oxidation decreased if leucine supply was limited, thereby indicating that excess leucine is not required to sustain milk protein yields. Bequette et al. (1996) reported that increasing the supply of 
leucine to the mammary gland did not enhance milk protein output, but did increase its oxidation in the mammary gland. Lapierre et al. (2002) also showed that only 0.16 of the increased supply of leucine available for absorption ended up in milk protein. This suggests that leucine was not the AA which was limiting production in the $200 \mathrm{~g} / \mathrm{kg} \mathrm{CM}$ ration, thereby suggesting that methionine and/or phenylalanine were the limiting AA.

\section{Conclusions}

Overall results under these conditions, which are representative of many contemporary US dairy rations, show that optimum levels for most response parameters overlapped in the range of $120-135 \mathrm{~g} / \mathrm{kg} \mathrm{CM}$ inclusion in diet DM. It seems clear that the high HPDDG ration was nutritionally limited by a combination of low MCP flow to the intestine and a low dietary delivery of lysine, resulting in a substantial reduction in lysine available for milk production. That predicted high rumen ammonia levels, due to the high RDP content of CM, did not limit MCP production for the $200 \mathrm{~g} / \mathrm{kg}$ CM ration suggests that total protein delivery to the intestinal absorptive site did not limit productive performance. Thus the limiting factor at the highest inclusion level of CM was likely availability of absorbable AA, with plasma levels suggesting methionine and/or phenylalanine as the most likely candidates.

\section{Acknowledgements}

The authors thank Mr. William van Die and the personnel (i.e., George, Nacho, Pedro) at Cloverdale Dairy for their interest, assistance and patience during the completion of the study. Efforts of the DHIA staff in Hanford in arranging and sorting extra milk test samples is also greatly appreciated. The senior author also thanks fellow students Jill Soderstrom, Grace Cun, Blanca Camacho and Jason Serrano in collecting and processing samples. Special thanks to Krystal Baker for going above and beyond in both assistance and support.

\section{References}

AOAC, 1997. Official Method of Analysis, vol. I., 16th ed. Association of official Analytical Chemists, Inc., MD, USA.

AOAC, 2006. Official Methods of Analysis of AOAC International, 18th ed. AOAC International, Arlington, VA

Appuhamy, J.A.D.R.N., Knapp, J.R., Becvar, O., Escobar, J., Hanigan, M.D., 2011. Effects of jugular-infused lysine, methionine, and branched-chain amino acids on milk protein synthesis in high-producing dairy cows. J. Dairy Sci. 94, 1952-1960.

Bequette, B.J., Backwell, F.R.C., MacRae, J.C., Lobley, G.E., Crompton, L.A., Metcalf, J.A., Sutton, J.D., 1996. Effect of intravenous amino acid infusion on leucine oxidation across the mammary gland of the lactating goat. J. Dairy Sci. 79, 2217-2224.

Boucher, S.E., Ordway, R.S., Whitehouse, N.L., Lundy, F.P., Kononoff, P.J., Schwab, C.G., 2007. Effect of incremental urea supplementation of a conventional corn silage-based diet on ruminal ammonia concentration and synthesis of microbial protein. J. Dairy Sci. 90, 5619-5633.

Canola Council of Canada, 2010. Annual Report. Canola Council of Canada, Winnipeg, MB, Canada.

Canola Council of Canada, 2011. Annual Report. Canola Council of Canada, Winnipeg, MB, Canada.

Chen, X.B., Gomes, M.J., 1992. Estimation of Microbial Protein Supply to Sheep and Cattle based on Urinary Excretion of Purine Derivatives - An Overview of the Technical Details. Int. Feed Res. Unit, Occasional Publ. Rowett Research Institute, Aberdeen, UK (edited and reprinted 1995). http://www.macaulay.ac.uk/IFRU/pdf/chema.pdf (accessed 20.12.2012).

Chen, X.B., Mejia, A.T., Kyle, D.J., Ørskov, E.R., 1995. Evaluation of the use of the purine derivative:creatinine ratio in spot urine and plasma samples as an index of microbial protein supply in ruminants: studies in sheep. J. Agric. Sci. 125, 137-143.

Chen, X.B., Ørskov, E.R., 2003. Research on Urinary Excretion of Purine Derivatives in Ruminants: Past, Present and Future. International Feed Resources Unit, Macaulay Land Use Research Institute, Craigiebuckler, Aberdeen, UK http://www.macaulay.ac.uk/IFRU/pdf/pd_review.pdf (accessed 20.12.12).

Chilliard, Y., Cissé, M., Lefaivre, R., Rémond, B., 1991. Body composition of dairy cows according to lactation stage, somatotropin treatment, and concentrate supplementation. J. Dairy Sci. 74, 3103-3116.

Chizzotti, M.L., Valadares Filho, S.C., Valadares, R.F.D., Chizzotti, F.H.M., Tedeschi, L.O., 2008. Determination of creatinine excretion and evaluation of spot urine sampling in Holstein cattle. Livest. Sci. 113, 218-225.

Christen, K.A., Schingoethe, D.J., Kalscheur, K.F., Hippen, A.R., Karges, K.K., Gibson, M.L., 2010. Responses of lactating dairy cows to high protein distillers grains or 3 other protein supplements. J. Dairy Sci. 93, 2095-2104.

Djouvinov, D.S., Todorov, N.A., 1994. Influence of dry matter intake and passage rate on microbial protein synthesis in the rumen of sheep and its estimation by cannulation and a non-invasive method. Anim. Feed Sci. Technol. 48, 289-304.

Ferguson, J.D., Galligan, D.T., Thomsen, N., 1994. Principal descriptors of body condition score in Holstein cows. J. Dairy Sci. 77, $2695-2703$.

Gonzalez-Ronquillo, M., Balcells, J., Guada, J.A., Vicente, F., 2003. Purine derivative excretion in dairy cows: endogenous excretion and the effect of exogenous nucleic acid supply. J. Dairy Sci. 86, 1282-1291.

Han, Y.K., Shin, H.T., Landis, J., 1992. Effect of level of feed intake on the excretion of purine derivatives and purine derivatives to creatinine ratio in the urine of sheep. Asian-Aust. J. Anim. Sci. 5, 465-468.

Hollmann, M., Allen, M.S., Beede, D.K., 2011. Diet fermentability influences lactational performance responses to corn distillers grains: a meta-analysis. J. Dairy Sci. 94, 2007-2021.

Johansen, H.N., Glitsø, V., Knudsen, K.E.B., 1996. Influence of extraction solvent and temperature on the quantitative determination of oligosaccharides from plant materials by high-performance liquid chromatography. J. Agric. Food Chem. 44, 1470-1474.

Johnson, C.M., Ulrich, A., 1959. Analytical Methods for Use in Plant Analysis. Bulletin 766. University of California, Agricultural Experiment Station, Berkeley, CA, pp. 26-78.

Lapierre, H., Berthiaume, R., Raggion, G., Thivierge, M.C., Doepel, L., Pacheco, D., Dubreuil, P., Lobley, G.E., 2005. The route of absorbed nitrogen into milk protein. Anim. Sci. 80, 11-22.

Lapierre, H., Blouin, J.P., Bernier, J.F., Reynolds, C.K., Dubreuil, P., Lobley, G.E., 2002. Effect of supply of metabolizable protein on whole body and splanchnic leucine metabolism in lactating dairy cows. J. Dairy Sci. 85, 2631-2641.

Lapierre, H., Doepel, L., Milne, E., Lobley, G.E., 2009. Responses in mammary and splanchnic metabolism to altered lysine supply in dairy cows. Animal 3 , $360-371$.

Liu, K.S., Rosentrater, K.A. (Eds.), 2011. Distillers Grains: Production, Properties and Utilization. CRC Press, Baca Raton, FL.

Mäntysaari, P., Mäntysaari, E.A., 2008. Relationship of body measurements and body condition score to body weight in modern Finnish Ayrshire cows. Acta Agric. Scand. A 58, 170-178 
Meyer, G.A., Keliher, P.N., 1992. Overview of analysis by inductively coupled plasma-atomic emission spectrometry. In: Montaser, A., Golightly, D.W. (Eds.), Inductively Coupled Plasmas in Analytical Atomic Spectrometry. VCH Publishers Inc., New York, NY, pp. 473-516.

Moorby, J.M., Dewhurst, R.J., Evans, R.T., Danelon, J.L., 2006. Effects of dairy cow diet forage proportion on duodenal nutrient supply and urinary purine derivative excretion. J. Dairy Sci. 89, 3552-3562.

Mulrooney, C.N., Schingoethe, D.J., Kalscheur, K.F., Hippen, A.R., 2009. Canola meal replacing distillers grains with solubles for lactating dairy cows. J. Dairy Sci. 92, 5669-5676.

National Research Council, 2001. Nutrient Requirements of Dairy Cattle, 7th rev. ed. National Academy Press, Washington, DC.

Nernberg, L., 2012. After the crush: increasing canola demand through research and promotion. In: Proc. Sask Canola Producer Conference and AGM, January 12, Saskatoon, SK, Canada.

Nichols, J.R., Schingoethe, D.J., Maiga, H.A., Brouk, M.J., Piepenbrink, M.S., 1998. Evaluation of corn distillers grains and ruminally protected lysine and methionine for lactating dairy cows. J. Dairy Sci. 81, 482-491.

Piepenbrink, M.S., Schingoethe, D.J., Brouk, M.J., Stegeman, G.A., 1998. Systems to evaluate the protein quality of diets fed to lactating cows. J. Dairy Sci. 81 , $1046-1061$.

Reuter, D.J., Robinson, J.B., Peverill, K.I., Price, G.H., 1986. Guidelines for collecting, handling and analyzing plant materials. In: Reuter, D.J., Robinson, J.B. (Eds.), Plant Analysis and Interpretation Manual. Inkata Press, Melbourne, Australia, pp. 20-35.

Reynal, S.M., Broderick, G.A., 2005. Effect of dietary level of rumen-degraded protein on production and nitrogen metabolism in lactating dairy cows. J. Dairy Sci. 88, 4045-4064.

Robinson, P.H.,1996. Rumen protein metabolism - predicting outflow. In: Proc. Eastern Nutrition Conference. Canadian Feed Industry Association, Ottawa, Ontario, Canada.

Robinson, P.H., 2009. SHIELD Dairy Ration Evaluator. Department of Animal Science, UC Davis, Davis, CA http://animalscience.ucdavis.edu/faculty/ robinson/Projects/pdf/SHIELDProject.pdf (accessed 20.12.12).

Robinson, P.H., 2010. Impacts of manipulating ration metabolizable lysine and methionine levels on the performance of lactating dairy cows: a systematic review of the literature. Livest. Sci. 127, 115-126.

Robinson, P.H., Meyer, D., 2010. Total Mixed Ration (TMR) Sampling Protocol. ANR Publication 8413. ANR Publications, University of California, Berkeley, CA.

Robinson, P.H., Uden, P., de Blas, C., Blank, R., 2006. Some experimental design and statistical criteria for analysis of studies in manuscripts submitted for consideration for publication. Anim. Feed Sci. Technol. 129, 1-11.

Rulquin, H., Pisulewski, P.M., 2006. Effects of graded levels of duodenal infusions of leucine on mammary uptake and output in lactating dairy cows. J. Dairy Res. 73, 328-339.

SAS Institute Inc., 2000. SAS/STAR ${ }^{\circledR}$ Software: Changes and Enhancements, Release 9.2. SAS Institute Inc., Cary, NC.

Swanepoel, N., Robinson, P.H., Erasmus, L.J., 2010. Amino acid needs of lactating dairy cows: impact of feeding lysine in a ruminally protected form on productivity of lactating dairy cows. Anim. Feed Sci. Technol. 157, 79-94.

Tracy, M.L., Moeller, G., 1990. Continuous flow vapour generation for inductively coupled argon plasma spectrometric analysis. Part 1. Selenium. J. Assoc. Off. Anal. Chem. 73, 404-410.

Tyrell, H.F., Reid, J.T., 1965. Prediction of the energy value of cow's milk. J. Dairy Sci. 48, 1215-1223.

USDA Foreign Agricultural Services, 2011. Global Agricultural Information Network. Gain Report Number CA11015. USDA, Washington, DC.

Vagnoni, D.B., Broderick, G.A., 1997. Effect of replacing alfalfa silage with high moisture corn on ruminal protein synthesis estimated from excretion of total purine derivatives. J. Dairy Sci. 80, 1703-1712.

Valadares, R.F.D., Broderick, G.A., Valadares Filho, S.C., Clayton, M.K., 1999. Effect of replacing alfalfa silage with high moisture corn on ruminal protein synthesis estimated from excretion of total purine derivatives. J. Dairy Sci. 82, 2686-2696.

Van Soest, P.J., Robertson, J.B., Lewis, B.A., 1991. Methods for dietary fibre, neutral detergent fibre, and non-starch polysaccharides in relation to animal nutrition. J. Dairy Sci. 74, 3583-3591.

Wattiaux, M.A., 1994. Body condition scores. In: Dairy Essentials. Technical Dairy Guide. The Babcock Institute Publications, University of Wisconsin, Madison, WI http://babcock.wisc.edu/node/170 (accessed 20.12.12).

Wildman, E.E., Jones, G.M., Wagner, P.E., Boman, R.L., 1982. A dairy cow body condition scoring system and its relationship to selected production characteristics. J. Dairy Sci. 65, 495-501.

Williams, E.J., 1949. Experimental designs balanced for the estimation of residual effects of treatments. Aust. J. Sci. Res. A: Phys. Sci. 2, 149.

Wisner, R., 2010, December. Distillers Grain Price Relationships and Export Developments. AgMRC Renewable Energy Climate Change Newsletters. Agricultural Marketing Resource Center, Iowa State University, Ames, IA http://www.agmrc.org/renewable_energy/ethanol/distillers-grain-pricerelationships-and-export-developments/ (accessed 20.12.12).

Young, E.G., Conway, C.F., 1942. On the estimation of allantoin by the Rirnmi-Schryver reaction. J. Biol. Chem. 142, 839-853. 